
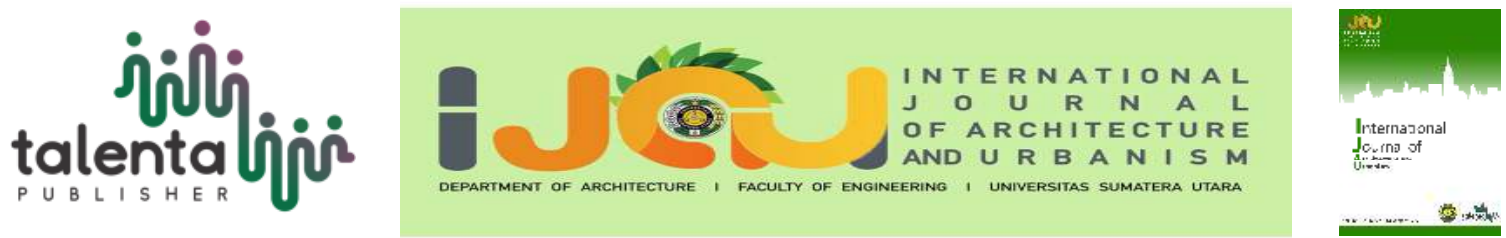

\title{
Gateway District: The Opportunities of City Gate as a Growth Centre Reinforcement
}

\author{
Lindarto D. ${ }^{1}$, Harisdani D.D. ${ }^{1}$ \\ ${ }^{1}$ Departement of Architecture, Universitas Sumatera Utara, Medan, Indonesia
}

\begin{abstract}
Inauguration Kuala Namu Airport in 2012 has established access to area of Medan, Binjai, Deli Serdang and Karo (Mebidangro) region as a leading tourist destination. As the central hub to the area declared Mebidangro, Medan city railway station in the center of Merdeka Square as a main gate. The facts show that the concept of the gates are inadequate in physical appearance as well as activities that memorable as the charming gateway. In simple terms refers to a landmark gate marker. City revitalization in addition to using a model of revitalization can be done with a model revealing the wisdom of local activities. In the era of visual communication and local activities as opportunities for the development of a place, the potential Merdeka Square neighborhood activities become eligible as an aspect of quality amplifier forming place (reinforcement place making). With the method of observation and analysis of spatial solid-void it is obtained that the Merdeka Square is a model of district gateway rather than a landmark gateway by appearing the activities of local commercial, local culture, heritage adventure, social interaction as a trigger activity. These findings are useful for policy makers to look at the Merdeka Square as forming productivity growth Medan city center as well as reinforcing the identity of Medan city.
\end{abstract}

Keyword: gateway district, growth center, medan merdeka square

\section{Introduction}

North Sumatra as one of the rapidly growing provinces in the western part of Indonesia in 2013 inaugurated the Kuala Namu International Airport as a hub of international and domestic air transport. The existence of the airport open accessibility of tourist destinations to the region of North Sumatra. Medan's demographic bonus as a national strategic regional core city, Mebidangro making an entrance for a sightseeing trip to the city hinterland [1].

One pathway Medan from Kuala Namu Airport is Medan city railway station. Medan city railway station dealing with Medan Merdeka Square (commonly known as the Esplanade) a square with the marker zero point of the Medan city. This railway station is identical to the location of a public space Merdeka Square. The colonial town design of Medan puts Esplanade as the city center is surrounded with trade center Pajak Ikan Lama, Kesawan Chinatown, Kantor Pos building, Balai Kota government center and railway station.

\footnotetext{
*Corresponding author at: Jl. Perpustakaan, Gedung J7, Kampus USU, Medan 20155, Indonesia

E-mail address: dwi.lindarto@usu.ac.id,devin.defriza@usu.ac.id
} 
Tourist attraction identity can be built through the disclosure of the potential of the building's architecture and the city's architecture [2]. As a place begins the influx of tourists into the city of Medan, Merdeka Square station whose distinctive architecture has yet to show an attractive appearance. Circulation design and orientation marker is not enough to give comfort. Spatial linkages between indoor and outdoor space of railway station showed a striking gap atmosphere. Actually railway station heritage is a valuable asset as a leading tourist destination recorded the Netherlands, France, Yogyakarta and Jakarta railway station has been pointed out that successful creative work. Reality indicates that the Merdeka Square station entrance which is conceptualized as a magnificent city does not appear in physical appearance and activities that take place [3].

From the economic view of the city, a place of quality tourism will affect the level of comfort and satisfaction of tourists who have an impact on the length of stay, use of accommodation and transport expenses. This will increase revenue. Early research shows the potential area of Medan Merdeka Square as a "city image" or the image of the city of Medan. Revitalization of the city in addition to using a model of revitalization [4], can also be done with a model revealing the wisdom of local activities. In the era of visual spatial and local activities to elemental quality room establishment, the potential physical and non-physical Merdeka Square neighborhood becomes eligible to be disclosed as an aspect of quality amplifier forming place (reinforcement place making).

\section{Literature Review}

In the World Trade Report (WTO) in 2007 (Figure 1) [5], stated that the attractiveness of tourist destinations and serving experience can be shaped partly by grain attractions/performances, potential indoor facilities of public or buildings, convenience of access, cultural activities of the community, the image of the area and the distinctive character town atmosphere, affordability.

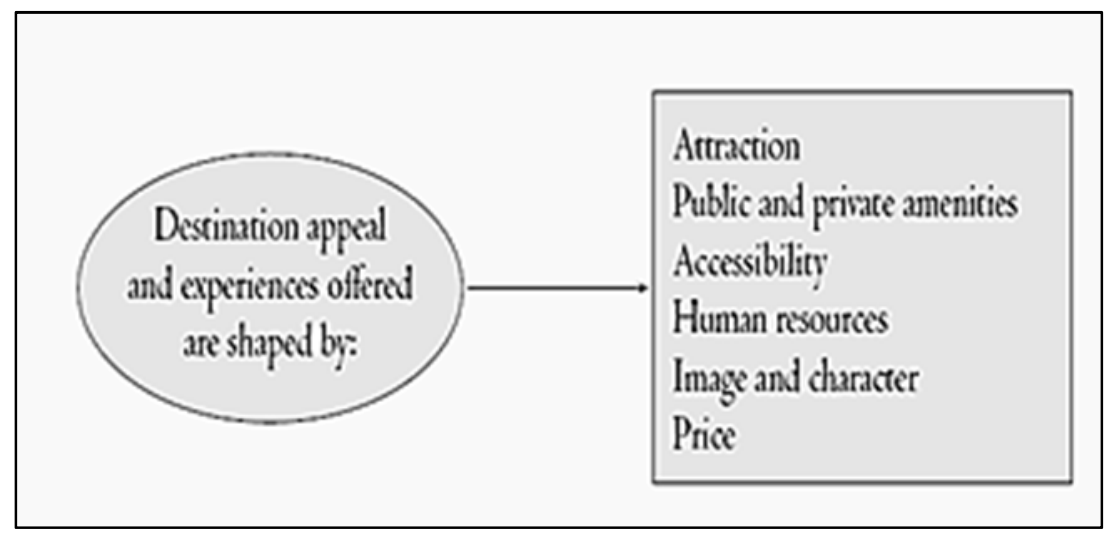

Figure 1. Elements of Fascination Destination (Source: WTO, 2007) 
How can a planned tourist destination is to identify and select potential elements of local and mixed to achieve a positive image of the region [6]. A significant tourist destination promises a memorable travel experience unique to that goal. This tourist destination is also evocative memories reinforcement repetition pleasant experience at the venue [7] [8].

How do strategies incorporation boosting agent destination can meaningfully by means of strengthening local potential, organizing events with the condition of a charming, human resource management of local interest in the attractions / local celebration, treats local story, fable, memories of romance, myth that building an image the memory of that place [9].

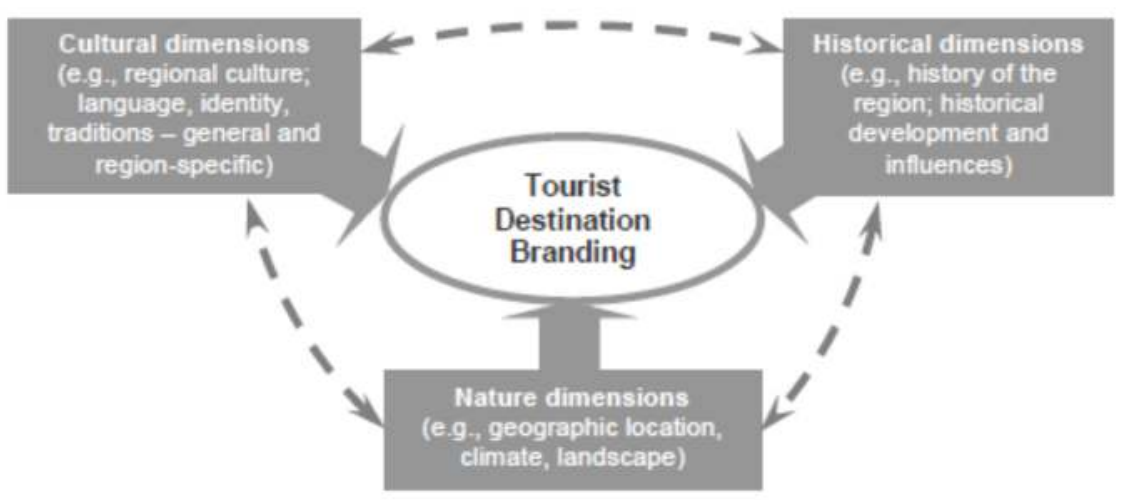

Figure 2. Model establishment of meaningful tourist destination (Source: Iliachenko, 2005)

One model of the formation of a tourist destination (Figure 2), means among other things is the integration and management of multiple elements dimension of local wisdom [10], namely: the cultural dimension (language, art, local, tribal identity, activities of religion), historical dimension (the history of the city area, the architectural history of the city), and natural dimension (attractive location, climate and landscape).

\section{Methodology}

In The Image of The City [11], Lynch express there are at least five elements of the node, path, edge, landmark and district as the image of the city elements. In this case the gate of the city is often interpreted by building a monument (sculpture) as a physical expression to mean the entrance, directional, orientation, marker. In line with the method of collecting memories (mapping experiencing) performed by Kevin Lynch, this research is descriptive qualitative, observation and spatial analysis of solid-void [12] and literature review revealed the city's image element strengthening the city gates in addition to landmark gateway into a form that is more memorable gateway district. 


\section{Result and Discussion}

In a study on the perception of the image of the historic district in the city center [13], resulting that the difference in the understanding of the overall image of the city that influenced the respondent group of experts, students and general public. In this understanding of the differences, there is one common factor to be understood in shaping the image of the region of the main characters, namely the establishment of the area as a place, is influenced by the familiarity of the environment, the physical form (architecture) and the perception of respondents. Furthermore, in the study forming the identity of the city, it takes a city gate entrance marker. City gate manifested in the presence of component identity, signs and representations are applied to the components of urban space with public functions (public), the function of informative and recreational functions [14].

Merdeka Square at the core of the city with its original historic buildings around which potential Lonsum building, Bank Mandiri building, Balai Kota, Hotel De Boer (now Inna Medan), Kantor Pos building, Kesawan heritage district and Pajak Ikan Lama trade center. There hospitality infrastructure and adequate public facilities in this region. Potential form of community activities in outer space in the area around Merdeka Square bordering the railway station include the Car Free Day activities such as jogging pedestrian activity around the square, bike community activities and skating sport. People use around the site by selling merchandise or special snacks of Medan. Car Free Day atmosphere lasts until 11:00 pm.

Achievement of Medan City Gates plans on putting Merdeka Square area that the city gate can not only interpreted as a monument or Gapura as usual. In the case of Merdeka Square and railway stations as a magnet for tourist visits can be upgraded to "Gateway District" rather than as the expansion and the generation of local spatial potential in the region. Briefly gateway/gate is not interpreted by the display of monuments alone but as a destination area that characterizes the diversity of activities and the formation of an artificial city of Medan is symbolic and artistic.

Gateway District planned scenario place begins in a railway station arrivals gate that is more attractive and able to aim orientation toward Merdeka Square. On arrival gate signage markers have seen their way toward the left to Titi Gantung bridge to the attractions of Medan souvenir shop and street vendors snack area. Being directed towards the front of the Kios Toko Buku field and thematic exhibitions of art and culture the city of Medan. Tourists will be invited to the right spot to watch attractive monument of old Dutch locomotive tobacco plantation era (Figure 3). Here are provided the location of the self-photo provides uniform tobacco industry officials Deli Dutch era. 


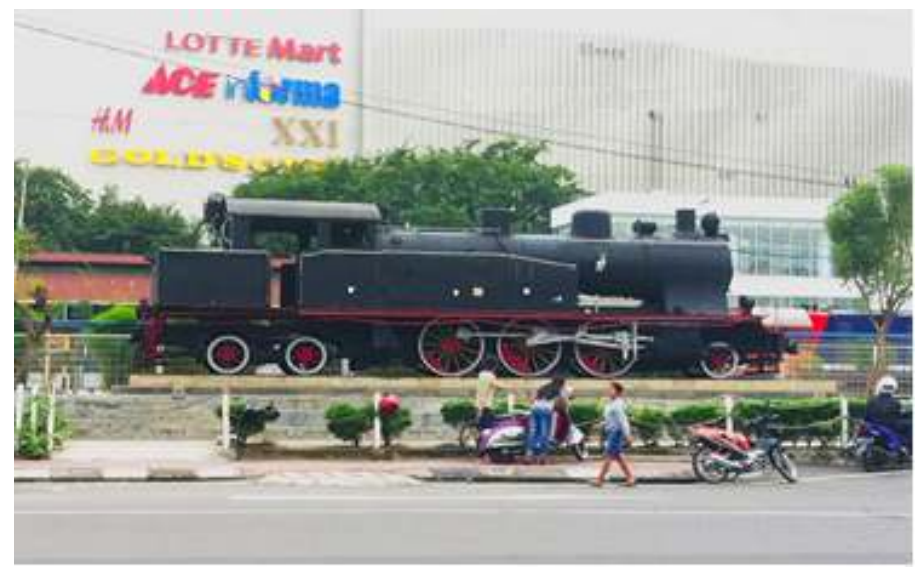

Figure 3. Dutch era Locomotive Monument in Medan Merdeka Square

(Source: Author observation, 2019)

Another point of interest is the monument of Medan zero kilometer in front of heritage buildings Kantor Pos Medan. With the background of the legendary Hotel De Boer (Figure 4) then this area becomes crowded node where even now has become a community gathering points of bicycles and pedestrians. Rating if the desire to stay at the heritage hotel Hotel De Boer is the right choice. A little to the left will be neatly lined colonial buildings that Bank Indonesia building and the Balai Kota has been conserved adaptive re-use becomes Aston Hotel.

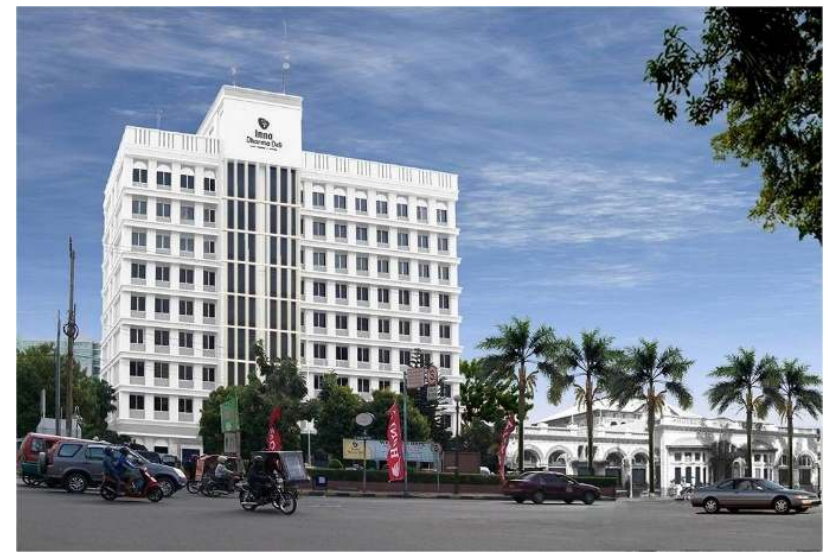

Figure 4. Hotel De Boer (now Inna Hotel) in Medan Merdeka Square

(Source: Author observation, 2019)

There is a spatial linkage relationship between the Medan city railway station, Locomotive Monument, Kios Toko Buku, and Titi Gantung on Merdeka Square by linking the activities of attractions/local activities, public facilities, accessibility, human resources, image and character of the area as a potential District Gateway (Figure 5 and Figure 6). 


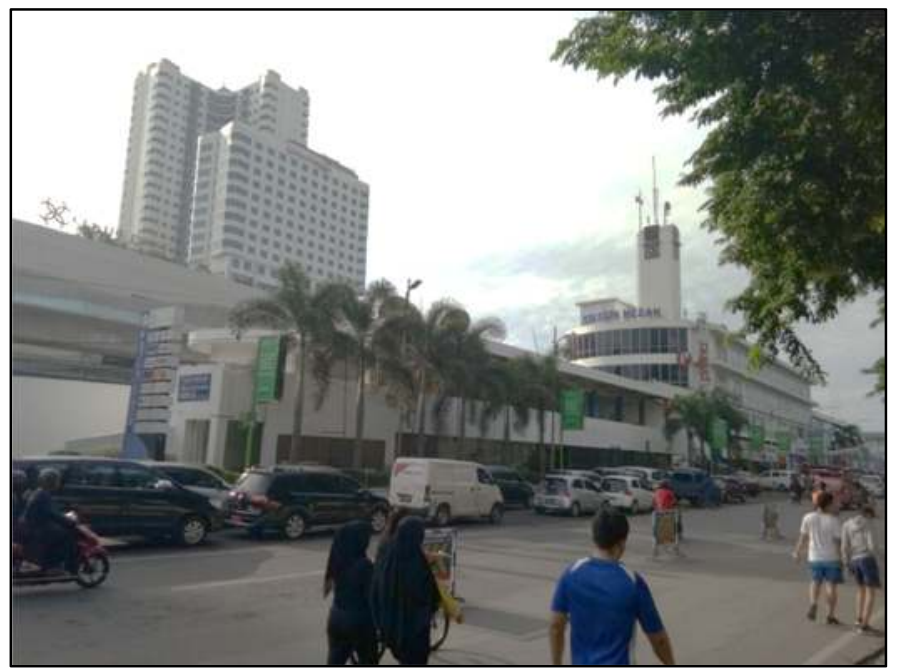

Figure 5. Potential Gateway District around railways station in Medan Merdeka Square (Source: Author observation, 2019)

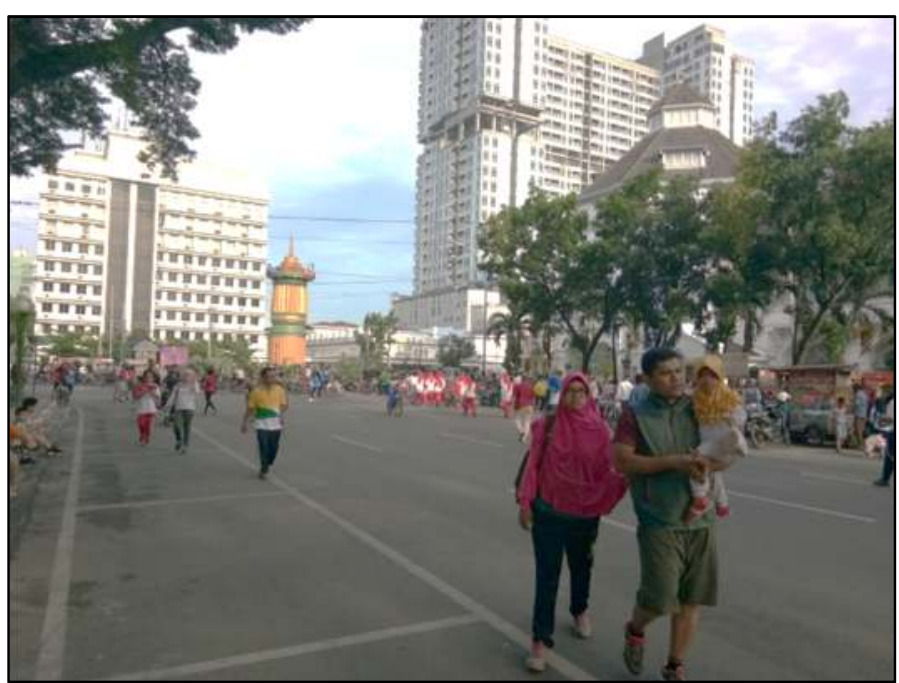

Figure 6. Potential Gateway District activities in Medan Merdeka Square (Source: Author observation, 2019)

Provision of facilities for public street furniture such as seats (Figure 7) and decorative lighting city room accommodates enjoyment activities with visual treat towards the historical buildings, under the shade of a big tamarind tree, street musicians show with thematic exhibitions and special snacks treats the city of Medan. This city open space can be used also for the activities of the souvenir center that will strengthen memories the city of Medan. 


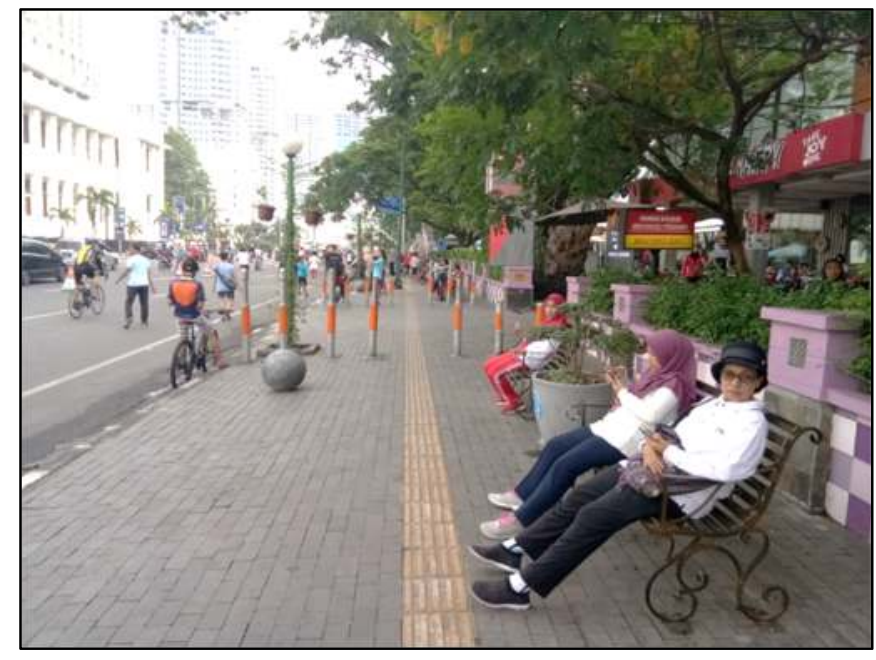

Figure 7. Potential Gateway District facilities in Medan Merdeka Square (Source: Author observation, 2019)

Merdeka Square neighborhood linkage will be formed with the ease of access to important nodal of railway station, Lonsum building, Bank Mandiri building, Balai Kota, Hotel De Boer (now Inna Medan), Kantor Pos building, Kesawan heritage district and Pajak Ikan Lama trade center. Movement of tourists visit can be done with local transport model uses a motor rickshaw decorated with typical of the city of Medan. The movement of productive economic activities in the area of Merdeka Square is consistent with the concept that combines street and square along with interesting activities in the locality strengthen local identity.

Developing gate of the Medan city through actions strengthening the physical facilities of the city and local activities typical of the area firstly focused on the area of railway station of Medan Merdeka Square as a hub of transportation as a "Gateway Landmark" could become more attractive with the application of the linkage between the nodal become "Gateway District", as forming productivity growth Medan city center as well as reinforcing the identity of Medan city.

\section{Conclusion}

Forming productivity growth Medan city center as well as reinforcing the identity of Medan city identity can be initiated through increased experience a more lasting and meaningful to improve the concept of Gateway Landmark into a Gateway District. In the implementation of development activities that identity is a comprehensive activity in the plan that involves the mindset of tourism, accessibility, potential local knowledge of local culture in the cooperation between the government, private sector and user communities as Medan Merdeka Square regional development stakeholders. 


\section{REFERENCES}

[1] Hadinugroho, D. L., Sirojuzilam, B., \& Aulia, D. N. (2017). The changes of land use and aerotropolis concept in Tembung region, Deli Serdang, Indonesia. International Journal of Development and Economic Sustainability, 5(1), 23-31.

[2] Anonymous (2009). Undang-undang Nomor 10 Tahun 2009, Tentang Kepariwisataan. Indonesia.

[3] Nasution, A. D., Harisdani, D. D., \& Napitupulu, P. P. (2017, March). The implementation of aerotropolis concept on new town planning and design in Mebidangro, Sumatera Utara. In IOP Conference Series: Materials Science and Engineering (Vol. 180, No. 1, p. 012293). IOP Publishing.

[4] Lindarto, D., \& Harisdani, D. D. (2019). MODEL RANCANGAN DESAIN REVITALISASI KAWASAN NIAGA (Studi Kasus: Pasar Petisah Medan). NALARs, 18(1), $1-8$.

[5] World Trade Report (2007). http://www.wto.org/english/res_e/booksp_e/anrep_e/ world_trade_report07_e.pdf (visited 2 Jan 2019).

[6] Cai, L. A. (2002). Cooperative branding for rural destinations. Annals of tourism research, 29(3), 720-742.

[7] Goeldner, C. R., \& Ritchie, J. B. (2007). Tourism principles, practices, philosophies. John Wiley \& Sons.

[8] Kaplanidou, K., \& Vogt, C. (2003). Destination branding: Concept and measurement. Travel Michigan and Michigan State University, Department of Park, Recreation and Tourism Resources, 1-7.

[9] Aaker, D. A. (2012). Building strong brands. Simon and Schuster.

[10] Iliachenko, E. (2005). Exploring culture, history and nature as tourist destination branding constructs: The case of a peripheral region in Sweden. In Nordic-Scottish Conference on Rural and Regional Development: 22/09/2005-25/09/2005.

[11] Lynch, K. (1960). The image of the city (Vol. 11). MIT press.

[12] Creswell, J. W., Hanson, W. E., Clark Plano, V. L., \& Morales, A. (2007). Qualitative research designs: Selection and implementation. The counseling psychologist, 35(2), 236264.

[13] Pettricia, H. A., Wardhani, D. K., \& Antariksa, A. (2014). Elemen Pembentuk Citra Kawasan Bersejarah Di Pusat Kota Malang. RUAS (Review of Urbanism and Architectural Studies), 12(1), 10-23.

[14] Pattymahu, D. R. (2016). Gerbang Sebagai Pembentuk Identitas Kota Studi Kasus Koridor Jalan Trans Sulawesi Di Malalayang Manado. Daseng: Jurnal Arsitektur, 5(2), 68-82.

[15] Djunaedi, A. (2015). Aspek Budaya Dalam Keistimewaan Tata Ruang Kota Yogyakarta (Cultural Aspect in the Speciality of Yogyakarta Urban Spatial Planning). Journal of Regional and City Planning, 26(3), 230-252. 